This is an author produced version of a paper published in Journal of agricultural and food chemistry

This paper has been peer-reviewed but may not include the final publisher proof-corrections or pagination.

Citation for the published paper:

Hossain, Shakhawat; Bergkvist, Göran; Berglund, Kerstin; Glinwood, Robert; Kabouw, Patrick; Martensson, Anna; Persson, Paula. (2014)

Concentration and Time Dependent Effects of Isothiocyanates Produced from Brassicaceae Shoot Tissues on the Pea Root Rot Pathogen Aphanomyces euteiches. Journal of agricultural and food chemistry. Volume: 62, Number: 20, pp 4584-4591. http://dx.doi.org/10.1021/jf501776c.

Access to the published version may require journal subscription. Published with permission from: ACS publications.

Epsilon Open Archive http://epsilon.slu.se 


\section{Concentration and Time Dependent Effects of Isothiocyanates Produced from Brassicaceae Shoot Tissues on the Pea Root Rot Pathogen Aphanomyces euteiches}

Shakhawat Hossain $^{\mathrm{a}^{*}}$, Göran Bergkvist ${ }^{\mathrm{a}}$, Kerstin Berglund ${ }^{\mathrm{b}}$, Robert Glinwood ${ }^{\mathrm{a}}$, Patrick Kabouw $^{\mathrm{c}}$, Anna Mårtensson ${ }^{\mathrm{b}}$ and Paula Persson ${ }^{\mathrm{a}}$

${ }^{a}$ Swedish University of Agricultural Sciences, Department of Crop Production Ecology, P.O. Box 7043, SE-750 07 Uppsala, Sweden.

${ }^{\mathrm{b}}$ Swedish University of Agricultural Sciences, Department of Soil and Environment, P.O. Box 7014, SE-750 07 Uppsala, Sweden.

${ }^{c}$ Department of Terrestrial Ecology, Netherlands Institute of Ecology (NIOO-KNAW), Boterhoeksestraat 48, 6666 GA Heteren, The Netherlands.

*Corresponding author (Tel: +46-1867-2349. Fax: +46-1867-2890. Shakhawat.Hossain@slu.se) 
1 Abstract: Isothiocyanates (ITCs) hydrolysed from glucosinolates (GSLs) in Brassicaceae

2 tissue are toxic to soil organisms. In this study, the effect of aliphatic and aromatic ITCs

3 from hydrated dry Brassicaceae shoot tissues on mycelium and oospores of the pea root

4 rot pathogen Aphanomyces euteiches was investigated. The profile and concentrations of

5 GSLs in two test-Brassicaceae species, Sinapis alba and Brassica juncea, and the ITCs

6 from the dominant hydrolysed parent GSLs were monitored. The concentrations of

7 dominant ITCs and pathogen exposure time were evaluated in in vitro experiments. The

8 greatest effect on the pathogen was observed from aliphatic ITCs hydrolysed from $B$.

9 juncea tissue, and the effect depended on the ITC concentration and exposure time. ITCs

10 were more effectively hydrolysed from $B$. juncea GSLs than from $S$. alba GSLs, i.e. the

11 ITC/GSL ratio was higher in B. juncea than in $S$. alba tissue, giving a different release

12 pattern. The release of phenylethyl ITC, which was common to both species, followed a

13 similar pattern to the dominant ITC in each crop species. This suggests that traits other

14 than GSL content, e.g. plant cell structure, may affect the release of ITCs and should

15 therefore influence the choice of species used for bio-fumigation purposes.

17 Keywords: Brassicaceae, glucosinolate, isothiocyanate, Aphanomyces euteiches, pea

18 root rot 


\section{INTRODUCTION}

25 Pea root rot caused by the pathogen Aphanomyces euteiches Drechs is a serious problem

26 in pea production worldwide. ${ }^{1-3}$ The pathogen can persist in the soil for long periods

27 without a host plant due to the thick protective cell walls of the Aphanomyces oospores.

28 When oospores are stimulated to germinate by pea root exudates ${ }^{4}$, a short mycelium

29 strand and a sporangium is produced. The sporangium releases zoospores that attack the

30 pea roots. ${ }^{5}$ Pea root rot is difficult to control as there are no available pea cultivars with

31 an acceptable level of resistance. ${ }^{6}$ Further, synthetic fungicides may have a negative

32 environmental impact, and certain agents have been prohibited, for example within the

33 European Union ${ }^{7}$. The commonly recommended way to control A. euteiches is therefore

34 to leave intervals (6-8 years) between pea crops in the rotation. ${ }^{8}$

35 Many plants of the family Brassicaceae (brassica) can suppress soil-borne organisms

36 when grown as cover crops, or when added as plant residues to infested soil. ${ }^{9-11}$ In field

37 studies, Sinapis alba (white mustard) reduced the development of Aphanomyces pea root

38 rot when used as green manure. This reduction was enhanced when white mustard was

39 used for a second consecutive year. ${ }^{12}$ Studies under greenhouse conditions showed that

40 incorporating cabbage tissue after growth in contaminated soil gave close to a 10 -fold

41 reduction in pea root rot disease severity. ${ }^{13}$ Suppressive effects of brassica tissues are

42 associated with the glucosinolate class of chemicals (GSLs) present in the tissues. ${ }^{10}$ The

43 bio-fumigation concept in agricultural systems was introduced by Australian scientists in

44 the 1990s and includes practices to relieve the pressure of soil pests and pathogens by the

45 use of brassica crops. ${ }^{14}$ The concept is based on the toxic volatile compounds produced

46 from hydrolyzed GSLs. ${ }^{10,13,15,16}$ When brassica crop tissues are damaged, GSLs are 
47 hydrolysed by myrosinase to form volatile isothiocyanates (ITCs), thiocyanates, water-

48 soluble nitriles and epithionitriles. ${ }^{10,17}$ The composition and quantity of the produced

49 substances depend on the parent GSL. The type and concentration of GSLs vary between

50 brassica species, cultivars and vegetative parts and are also influenced by plant

51 development stage. ${ }^{16,18,19}$ The GSLs are classified as aliphatic, aromatic or indolyl based

52 on their chemical structure. ${ }^{10,20}$ Isothiocyanates suppress a wide range of organisms,

53 including the soil-borne pathogen A. euteiches. ${ }^{21}$ A study has demonstrated that volatile

54 compounds from decomposing cabbage tissues inhibit hyphal growth of A. euteiches, and

55 that the pathogen is unable to grow further when placed in fresh air after exposure,

56 although the active substance was not specified ${ }^{9}$. The suppressive effects depend on the

57 composition and concentration of ITCs. ${ }^{22}$ The chemical structure of ITCs influences their

58 mode of action meaning that different ITCs may show varying levels of toxicity at the

59 same concentration. ${ }^{23-25}$ An aliphatic structural group attached to the nitrogen in the basic

60 ITC structure generally confers greater toxicity than an aromatic structure. ${ }^{26}$ Generally,

61 the toxicity of ITCs decreases as the size of the organic group increases. ${ }^{27,28}$ Aliphatic

62 ITCs bind directly with protein molecules inside cells and inhibit their activity whereas

63 aromatic ITCs first interact with the cell membrane changing its electrophilic properties

64 before entering the cell ${ }^{23}$ and reducing cell activity. ${ }^{29}$

65 Many different brassica-derived materials have been used to study aspects of bio-

66 fumigation, such as fresh plant tissues, rape seed meal, freeze dried plant tissues and oil

67 extracts, but pure ITCs have also been used. ${ }^{18,30-32}$ Shoot tissue comprises the greater part

68 of the brassica plant material when it is used for bio-fumigation in practice. Here, we 
69 evaluate a simple, reproducible system for studying shoot tissue effects on a plant

70 pathogen in vitro, using low temperature drying of the plant material. ${ }^{13,33}$

71 Our overall aim was to discover how brassica plant tissues can be used for bio-

72 fumigation to reduce the occurrence of root rot on peas caused by A. euteiches. Our

73 specific objectives were to compare crop species with different GSL compositions to

74 generate knowledge on the choice of brassica crop for bio-fumigation in the control of

75 pea root rot. We tested the hypotheses that 1) ITCs from hydrolysed aliphatic-GSLs in $B$.

76 juncea shoot tissue are more effective than ITCs from aromatic-GSLs in $S$. alba shoot

77 tissue at reducing the ability of A. euteiches oospores to cause pea root rot 2) the lethal

78 effect of aliphatic ITCs from shoot tissues on the growth of A. euteiches depends on the

79 concentration of ITCs and time of pathogen exposure and 3) the release patterns of ITCs

80 from $B$. juncea and $S$. alba are different and influence the suppressive effects on $A$.

81 euteiches.

\section{MATERIALS AND METHODS}

84 Plant materials. Air dried shoot tissues of two GSL-containing plant species, Brassica 85 juncea (cv. Pacific Gold) and Sinapis alba (cv. Architect), a non-GSL plant species, 86 Secale cereale (cv. Amilo) and a water control were compared for their effect on 87 oospores and mycelium of $A$. euteiches. The effect of volatile compounds produced from

88 hydrated shoot tissues was studied in in vitro experiments. The most effective plant 89 species was chosen for dose and exposure-time experiments, compared with the effect of 90 chemical solutions of the dominant ITCs from the two brassica species. The composition 
91 of GSLs in B. juncea and S. alba dry shoot tissues and of ITCs produced from hydrated

92 tissues were analysed.

93

94 Shoot tissue production. Three cover crops, S. alba, B. juncea and S. cereale were 95 grown in garden soil (Hasselfors Garden AB, Sweden) in the greenhouse. A complete 96 nutrient solution (Cederroth International AB, Sweden) was applied at regular intervals

97 together with additional $\left(\mathrm{NH}_{4}\right)_{2} \mathrm{SO}_{4}$ to enhance GSL production. Shoot tissues were

98 harvested at soil level when $B$. juncea and $S$. alba reached the flowering stage. The

99 tissues were dried at $35{ }^{\circ} \mathrm{C}$ for $72 \mathrm{~h}$ then ground separately four times at $6000 \mathrm{rpm}$ to a

100 fine powder. The ground shoot tissues were stored in air-tight containers and kept in a 101 dark and dry place until use.

102

103 Aphanomyces euteiches inoculum. Aphanomyces euteiches strain 5035:2A was used in

104 all experiments (obtained from F. Heyman, Department of Forest Mycology and Plant

105 Pathology, Swedish University of Agricultural Sciences, Uppsala, Sweden). The strain

106 was maintained on corn meal agar (CMA) (Oxoid Ltd., UK) at $6{ }^{\circ} \mathrm{C}$ and was used for soil

107 inoculation ${ }^{34,35}$. For the production of oospore inoculum, the A. euteiches strain was

108 cultured in oat meal broth for four weeks. It was homogenised, oospore concentration

109 was calculated then it was mixed with talcum powder (VWR International AB, Sweden)

110 and dried. The dry inoculum material was sieved through a 1-mm mesh net and stored at

$1114{ }^{\circ} \mathrm{C}$ until use.

112 
113 Field soil. Soil was collected from an agricultural field in Giresta, Enköping, Sweden,

114 and tested for the absence of A. euteiches. The soil consisted of $46 \%$ clay, $48 \%$ silt, $2 \%$

115 sand and $4 \%$ organic matter. The organic matter content was estimated by loss on

116 ignition. The soil contained $1.5 \mathrm{mg} \mathrm{N} / \mathrm{mL}$ and the $\mathrm{pH}\left(\mathrm{H}_{2} \mathrm{O}\right)$ was 7.7. The soil was sieved

117 through a $0.6-\mathrm{cm}$ mesh, stored at $4{ }^{\circ} \mathrm{C}$ with soil moisture content maintained at $21 \%$

118 during storage. For some experiments the soil was sterilised by autoclaving twice at 121

$119{ }^{\circ} \mathrm{C}$ for $30 \mathrm{~min}$.

121 Oospore volatile exposure and bioassay. One gram of dry shoot tissue of B. juncea, $S$.

$122 a l b a$ and $S$. cereale was transferred separately to $220 \mathrm{~mL}$ plastic cups $(8.9 \mathrm{~cm}$ diameter).

123 Four grams of talcum powder containing about $2.8 \times 10^{4}$ oospores was spread

124 homogenously on a filter paper placed in a $9 \mathrm{~cm}$ diameter sieve (mesh $1 \mathrm{~mm}$ ) and placed

125 on top of the cup. At the start of the experiment $5 \mathrm{~mL}$ sterilized de-ionized water was

126 added to the tissue and another plastic cup was immediately placed upside down on top of

127 the sieve as a lid. The container was sealed with several layers of Parafilm (Sigma-

128 Aldrich, Sweden AB) and placed in the dark at $24{ }^{\circ} \mathrm{C}$ for ten days. Sterilized de-ionised

129 water was used as control and three replicates per treatment were performed.

130 After 10 days of incubation, the oospore-talcum powder was removed from the 131 container and $0.8 \mathrm{~g}$ of the $4 \mathrm{~g}$ treated powder was mixed with $80 \mathrm{~mL}$ sterilized and non-

132 sterilized soil. Four sub-samples, $20 \mathrm{~mL}$ each, of the two infested soils were transferred to

$13385 \mathrm{~mL}$ pots. One pea seed (cv. Clare) was sown on top of the infested soils in each pot

134 and was covered with an additional $5 \mathrm{~mL}$ non-infested soil. The pots were placed in a

135 greenhouse with light:dark period $14: 10 \mathrm{~h}$, temperature $24 / 19 \pm 2{ }^{\circ} \mathrm{C}$ and relative humidity 
136 (RH) $85 \pm 5 \%$. Soil moisture was adjusted daily to field levels in order to obtain optimal

137 infection conditions. All pea seedling roots were evaluated for root rot disease severity

138 three weeks after sowing. Each pea seedling was assigned a DSI (Disease Severity Index)

139 value based on the mean disease symptoms of the individual pea seedlings in the four

140 tubes representing each experimental unit. The scale for DSI ranges from 0 to $100(\%)$,

141 but each individual plant can only be assigned one of five scores for disease severity: $0 \%$

$142=$ healthy plant; $25 \%=$ root slightly discoloured; $50 \%=$ root extensively discoloured but

143 not shrunken; $75 \%=$ root extensively discoloured and shrunken; $100 \%=$ root partly or

144 completely rotted or plant dead. ${ }^{36}$

145

146 In vitro exposure of mycelium to volatiles- effect of dose. Dry shoot tissue, $60 \mathrm{mg}, 100$

$147 \mathrm{mg}$ and $140 \mathrm{mg}$ of B. juncea, S. alba and S. cereale was transferred separately to $220 \mathrm{~mL}$

148 plastic cups and mixed with $5 \mathrm{~mL}$ sterilized, de-ionized water. A water control was

149 included and all treatments had three replicates. The doses were determined after a pilot

150 study with $B$. juncea shoot tissues in which a $140 \mathrm{mg}$ dose completely inhibited pathogen

151 growth. A plug (7 mm diameter) from actively growing A. euteiches culture was placed

152 in the centre of a 9-cm CMA dish and placed as a lid on the top of cup immediately after

153 water was added to the dry plant tissues. Cup and dish were sealed with Parafilm and

154 incubated in a growth cabinet at $24{ }^{\circ} \mathrm{C}$ for four days. The colony diameter of A. euteiches

155 was measured on the lid daily using a measuring scale. After four days, the culture dish

156 lids were removed from the cups and placed in the same growth cabinet at $24{ }^{\circ} \mathrm{C}$ and

157 observed for further growth of A. euteiches. 
160 shoot tissue $(140 \mathrm{mg}$ ) was used to produce volatile compounds which were exposed to an

161 actively growing A. euteiches plug (7 mm diameter) put on fresh CMA dishes, as in the

162 dose experiment described above. Three exposure times were used, 40, 80 and 120

163 minutes, with three replicates of each. After exposure, dishes were incubated at $24{ }^{\circ} \mathrm{C}$ and

164 the colony diameter of A. euteiches was measured daily using a measuring scale on the

165 lid. After four days, the culture dish lids were removed from the cups and placed in the

166 same growth cabinet at $24{ }^{\circ} \mathrm{C}$ and observed for further growth of A. euteiches.

168 Exposure with ITC chemical standards. An in vitro experiment was performed using 169 authentic chemical standards (CS) of volatile compounds produced from B. juncea and $S$.

170 alba tissues, identified as described below. Standard solution mixtures were designed to

171 give concentrations of volatile compounds that closely resembled those recorded from

172 hydrated dry shoot tissue by collecting volatile compounds from plant tissue and CS

173 under the same conditions and quantifying the major components by gas chromatography

174 (Table 1). The B. juncea chemical standard mixture (B.juncea-CS) contained allyl ITC 40

$175 \mu \mathrm{g} / \mu \mathrm{l}$ (allyl ITC >98\% purity, Sigma-Aldrich, Sweden AB) and phenylethyl ITC $2 \mu \mathrm{g} / \mu 1$

176 (phenylethyl ITC 99\% purity, Sigma-Aldrich, Sweden AB). The S. alba chemical 177 standard mixture(S.alba-CS) contained benzyl ITC $30 \mu \mathrm{g} / \mu$ l (benzyl ITC 98\% purity, 178 Sigma-Aldrich, Sweden AB) phenylethyl ITC $5 \mu \mathrm{g} / \mu 1$ and allyl ITC $0.2 \mu \mathrm{g} / \mu 1$. All 179 chemical standard mixtures were dissolved in hexane.

180 One $\mu 1$ of each B.juncea-CS and S.alba-CS standard mixtures was placed in the centre 181 of a filter paper in a sealed plastic cup containing an actively growing A. euteiches 
182 mycelium (7 mm plug) placed on a fresh CMA dish and incubated in the dark at $22{ }^{\circ} \mathrm{C}$.

183 Hyphal growth was measured daily for four days using a measuring scale. The growth

184 was compared with the growth of an A. euteiches volatile-exposed culture where the

185 volatiles originated from $140 \mathrm{mg}$ hydrated dried tissues of $B$. juncea and $S$. alba, using

186 water and hexane as control treatments. For details of ITC analyses, see below.

188 Glucosinolate analysis. Glucosinolates were extracted from ground shoot tissue. ${ }^{37}$ In

189 brief, GLSs were extracted from $100 \mathrm{mg}$ of dry shoot tissue by $70 \% \mathrm{MeOH}$ which was

190 heated to $90{ }^{\circ} \mathrm{C}$ to deactivate myrosinase and therefore avoid degradation of the GSLs.

191 The extracts were transferred to a DEAE-Sephadex 25 column (Sigma, St. Louis, MO,

192 USA) before de-sulfating. Desulfoglucosinolates were separated and identified using

193 HPLC with an acetonitrile/Milli-Q water gradient. GSL detection was performed with a

194 photodiode array detector with $229 \mathrm{~nm}$ wavelength. The correction factors at $229 \mathrm{~nm}$ to

195 calculate the concentrations of GSLs were followed. ${ }^{38,39}$ The peaks of

196 desulfoglucosinolates were identified by comparison with standards on the basis of

197 retention times and ultraviolet spectra. Different concentrations of sinigrin (2-propenyl)

198 (Acros Organics, Fair Lawn, NJ, USA) were used as external standard and extracted

199 following the same procedure as the shoot tissue. The levels of GSLs were calculated on 200 the basis of dry weight of tissues.

202 Isothiocyanate analysis. Ground shoot tissue (140 mg) was placed in a glass dish and 203 moistened with 5 mL Milli-Q water. The suspension was immediately placed under a bell 204 shaped glass vessel $(380 \mathrm{~mL})$ with two openings and sealed with bulldog clips at $24 \pm 2{ }^{\circ} \mathrm{C}$ 
205 in the dark. Volatile compounds were collected by pulling air from outlet of the jar

206 through a glass liner containing Tenax TA (50 mg 60/80 mesh, Supelco, Bellefont, PA, 207 USA).

208 A positive pressure push-pull system was used, with charcoal-filtered air pushed 209 through an inlet into the vessel at $500 \mathrm{~mL} / \mathrm{min}$ and pulled out through the adsorbent at $210350 \mathrm{~mL} / \mathrm{min}$. The greater push rate prevented entry of contaminating volatiles. All 211 glassware and Teflon tubes (connecting air flow tubes) were washed with detergent, 212 distilled water and acetone and baked in an oven at $175{ }^{\circ} \mathrm{C}$ for at least 16 hours prior to 213 the entrainment. Charcoal filters and glass liners with Tenax TA were baked at $175{ }^{\circ} \mathrm{C}$ 214 and $220{ }^{\circ} \mathrm{C}$ respectively under $\mathrm{N}_{2}$ flow for $16 \mathrm{~h}$. Volatiles were collected for periods of 21510 min at $0-10,30-40,60-70$ and $120-130$ min after adding water to the tissue. The rest of 216 the time, the outlet of the glass vessel was open preventing the build-up of released 217 volatiles.

218 Concentrations of ITCs arising from the dosing of chemical standard (CS) solutions as 219 described above were determined by analysing one $\mu 1$ of either B.juncea-CS or S.alba-CS 220 mixtures put on a filter paper, placed inside a sealed plastic cup $(220 \mathrm{~mL})$. A glass liner 221 (with Tenax TA) was inserted through a hole in the plastic cup and air was pulled from 222 the cup at a flow rate of $350 \mathrm{~mL} / \mathrm{min}$. The aim was to sample at the peak concentration of 223 the major ITCs, which was after 60-70 min incubation for B.juncea-CS and 0-10 min for 224 S.alba-CS, as indicated by previous analysis of volatiles from B. juncea and S. alba plant 225 tissues. Volatiles were collected for $10 \mathrm{~min}$ and analysed by gas chromatography as 226 described below. 
For quantification, collected volatiles were analysed by gas chromatography (GC) on a

228 Agilent $6890 \mathrm{~N}$ with a flame ionization detector, equipped with an HP-1 column (100\%

229 dimethyl polysiloxane, $50 \mathrm{~m}, 0.32 \mathrm{~mm}$ i.d. and $0.52 \mu \mathrm{m}$ film thickness, J \& W Scientific,

230 USA), and fitted with an Optic 3 thermal desorption system (Atas GL Intl., Veldhoven,

231 Netherlands). An internal standard, $50 \mathrm{ng}$ of decane, was injected onto the glass liner

232 containing the sample prior to desorption. The liner containing the Tenax with absorbed

233 volatiles was placed directly into the injector and volatiles were thermally desorbed

234 starting at $30{ }^{\circ} \mathrm{C}$ for $0.5 \mathrm{~min}$ and rising at $16{ }^{\circ} \mathrm{C} / \mathrm{sec}$ to $250{ }^{\circ} \mathrm{C}$. The $\mathrm{GC}$ temperature

235 program was $30{ }^{\circ} \mathrm{C}$ for $3 \mathrm{~min}, 5{ }^{\circ} \mathrm{C} / \mathrm{min}$ to $150{ }^{\circ} \mathrm{C}$ for $0.1 \mathrm{~min}$ then $10{ }^{\circ} \mathrm{C} / \mathrm{min}$ to $250{ }^{\circ} \mathrm{C}$

236 for $15 \mathrm{~min}$, using hydrogen as carrier. The amount of each compound was calculated

237 relative to the internal standard.

238 For tentative compound identification, volatile samples from the treatments, $B$. juncea

239 hydrated plant tissue, B.juncea-CS mixture, S. alba hydrated plant tissue and S.alba-CS

240 mixture were collected as described above and analysed by coupled GC-mass

241 spectrometry using an Agilent 7890N GC coupled to an Agilent 5975C mass selective

242 detector (electron impact 70eV) fitted with an Optic 3 thermal desorption system (Atas

243 GL Intl., Veldhoven, Netherlands). The thermal desorption and GC oven temperature

244 programs were as described above. The carrier gas was helium with a flow rate of 1.3

$245 \mathrm{~mL} / \mathrm{min}$. Volatile compounds were identified by comparison against a commercially

246 available library (National Institute of Standards and Technology, NIST 08, USA) and by

247 comparison of mass spectra and retention indices with commercially available authentic

248 standards where available (Sigma-Aldrich AB, Sweden). Where standards were

249 unavailable, in some cases the retention index (Kovats Index, KI) of the substance could 
250 be matched with a previously published KI for the compound on the type of GC column

251 used in the current study (HP-1) (Figure 5).

252

253 ITC/GSL ratios. ITC/GSL ratios were calculated for selected GSLs. The GSL 2-

254 propenyl was the dominant GSL in $B$. juncea shoot tissues, and $p$-hydroxybenzyl GSL

255 was dominant in S. alba shoot tissues. 2-phenylethyl was detected in both plant tissues as

256 a common GSL. The detected GSLs were recorded as $\mu \mathrm{mol} / \mathrm{g}$ dry tissue in the GC

257 analysis (Table 2) and converted to $\mu \mathrm{g}$ for the selected GSLs using their molecular

258 weights. Estimated amounts of ITCs produced from their parent GSLs in hydrated plant

259 tissues during the initial 130 minutes were calculated (Figures 5 A \& B). Total amounts

260 of each ITC $(\mu \mathrm{g})$ produced in the initial $130 \mathrm{~min}$ of hydrolysis from $1 \mathrm{~g}$ hydrated dry

261 tissue was divided by the amount of each GSL $(\mu \mathrm{g})$ in $1 \mathrm{~g}$ dry tissue and multiplied by

262100 to determine the ITC/GSL ratios.

264 Statistical analysis. Mean DSI and radial growth of hyphae were transformed to their

265 natural logarithms. The experiments were generally analysed in accordance with their

266 completely randomized design. However, the soil treatment (sterilized vs. non-sterilized)

267 in the test of disease development on peas after oospore exposure to ITC volatile

268 compounds was treated as a sub-plot factor and the cover crops as main-plot factor in a

269 split plot design. The effect of cover crop, dose of cover crops, time of exposure to

270 volatile and cover crop/chemical were treated as fixed factors in all experiments and

271 replicate was treated as a random factor. Analyses of variances were made using the 
272 procedure linear model and least square means were compared using Tukey's test with a

$273 P \leq 0.05$ significance limit in $\mathrm{R}$ version 2.15.1 (The R Foundation, 2012)

274

275 RESULTS

276 Effects of volatile compounds on oospores. Volatile compounds from hydrated $B$.

277 juncea dry tissue strongly reduced the inoculum potential of A. euteiches oospores,

278 shown by a significant reduction in pea root rot symptoms compared to control shoot

279 tissues from the other species $(P<0.001, \mathrm{SE} \pm 0.120$; Figure 1$)$. The other cover crops or

280 soil sterilization before the experiment started had no significant effect on disease

281 development.

283 Effect of volatile compounds on hyphal growth- effect of dose. Brassica juncea shoot

284 tissue suppressed the hyphal growth of A. euteiches more efficiently than tissue from the 285 other species $(P<0.001)$ (Figure 2$)$. The hyphal growth of A. euteiches was more affected

286 by shoot tissue dose with $B$. juncea than with $S$. alba (dose X cover crop interaction, $287 P<0.001)$. The highest dose of $B$. juncea shoot tissue completely inhibited growth, and no 288 further growth was registered when these cultures were placed in fresh air. The volatile 289 compounds produced from the lower doses of B. juncea and the highest dose of S. alba 290 also reduced the hyphal growth of A. euteiches significantly compared with the water 291 control. No effect was found in the $S$. cereale tissue treatment.

292

293 Effect of volatile compounds on hyphal growth- effect of exposure time. The hyphal

294 growth of A. euteiches was affected by the time of exposure to volatile compounds 
295 produced from hydrolysed $B$. juncea shoot tissue $(P=0.002)$. The volatile compounds

296 from the $140 \mathrm{mg}$ dose of hydrated B. juncea shoot tissue completely inhibited the growth

297 of A. euteiches after exposure for 120 min (Figure 3). No further growth was observed

298 during the following days when the cultures were placed in fresh air.

300 Effects of chemical standard mixtures. Volatile compounds arising from the chemical

301 standard mixtures suppressed the growth of $A$. euteiches in vitro $(P<0.001)$. Volatile

302 compounds from hydrated B. juncea dried shoot tissue and both chemical standard

303 mixtures, B.juncea-CS and S.alba-CS, completely inhibited the growth of A. euteiches

304 (Figure 4). There was no further growth in the following days when the cultures were

305 placed in fresh air. Volatile compounds from hydrated S. alba tissue also caused some

306 reduction of hyphal growth compared to the water control. No inhibition of pathogen

307 growth was observed when exposed to the solvent hexane.

308

309 Glucosinolates in B. juncea and $\boldsymbol{S}$. alba shoot tissues. Both species contained aliphatic,

310 aromatic and indolyl GSLs. Total extracted GSL concentrations in S. alba were higher

311 than the concentration of GSLs in B. juncea. Sinapis alba contained one more GSL

312 compound than B. juncea. The aliphatic GSL 2-propenyl dominated in B. juncea and the

313 aromatic GSL $p$-hydroxybenzyl dominated in the S. alba tissue (Table 2).

315 Isothiocyanates from B. juncea and S. alba. Sinapis alba shoot tissue produced more

316 volatile compounds and a greater total amount of ITCs, than B. juncea. Sinapis alba and

317 B. juncea were dominated by aromatic benzyl ITC hydrolysed from the GSLs $p$ - 
318 hydroxybenzyl and benzyl, and aliphatic allyl ITC from the GSL 2-propenyl,

319 respectively. Both plant species produced the aromatic phenylethyl ITC (Table 3).

321 Pattern of ITC release from $B$. juncea and $S$. alba hydrated tissues. ITCs were

322 released faster from the GSLs in S. alba than from the GSLs in B. juncea tissue at the

323 beginning of hydrolysis (Figures 5 A \& B). The GSLs of B. juncea produced ITCs over a

324 longer time with increasing rate compared to ITCs from $S$. alba tissue. The estimated

325 ITC/GSL ratio of the dominant aliphatic 2-propenyl producing allyl ITC in $B$. juncea was

326 1.82. The ITC/GSL ratio for the dominant aromatic $p$-hydroxybenzyl and benzyl

327 producing benzyl ITC in S. alba was 0.56 . The ratio of the aromatic 2-phenylethyl GSL

328 producing phenylethyl ITC which was common to both species was 11.51 for $B$. juncea

329 and 15.51 for S. alba.

330 The release patterns of phenylethyl ITC were different for the two species, even

331 though the originating GSL 2-phenylethyl was the same in both species. Instead, it

332 followed the same pattern as the dominant allyl ITC in $B$. juncea and benzyl ITC in $S$.

333 alba (Figures 5 A \& B).

\section{DISCUSSION}

336 This study shows that volatile compounds produced by brassica shoot tissue have a strong

337 inhibitory effect on Aphanomyces euteiches. However the results also highlight the

338 importance of understanding the mechanisms behind the suppression when designing 339 systems where plants containing GSLs are used to control soil borne pathogens. We show 
340 that brassica species, dose of ITC and time of exposure interact in determining the effect

341 of the volatile compounds on A. euteiches mycelium or oospores.

342 We used shoot tissues from two brassica species with different GSL profiles. Although

343 we used different cultivars than in earlier investigations, produced the plant tissue under

344 greenhouse conditions, partly with artificial light, and dried the material to standardise

345 dosages, the variety and concentration of GSLs in B. juncea and S. alba shoot tissues was

346 similar to that found in earlier studies. ${ }^{10,15,42-45}$ This indicates that the GSL composition

347 remains consistent in the plant species despite differences in cultivar, growing conditions

348 and low temperature drying of the plant material. As a consequence of the composition of

349 GSLs, we found that the volatile compounds produced from B. juncea and S. alba were

350 dominated by allyl and benzyl ITCs respectively, which is in line with earlier studies. ${ }^{10}$

351 The thick walled, long lived oospores of A. euteiches are very different structures from

352 the thin walled A. euteiches hyphae. Nevertheless, suppression by direct exposure to

353 volatile compounds was shown for both these reproductive structures. For both mycelium

354 and oospore exposures, volatiles hydrolysed from $B$. juncea tissue were more effective

355 than volatiles from $S$. alba tissue. Previous investigations comparing the effects of

356 aliphatic and aromatic ITCs tested the survival of weevil larvae. ${ }^{30}$ The conclusion was

357 that the aliphatic allyl ITC is likely to have greater biological activity than the aromatic

358 ITCs, which is in line with the biological responses observed in the current study.

359 The in vitro data from the current study show that the amount of B. juncea tissue used

360 was lethal to A. euteiches, whereas the equivalent amount of $S$. alba tissue did not

361 completely prevent pathogen growth. This indicates that the highest dose of $S$. alba dry

362 shoot tissue did not produce a high enough concentration of volatile compounds to 
363 prevent pathogen growth. However in the experiment with chemical standards, the

364 volatile compounds released from the $S$. alba chemical mixture completely prevented

365 hyphal growth. The analysis of collected volatile compounds showed that the S. alba

366 chemical mixture produced 10 times more ITCs than S. alba hydrated dry shoot tissue. It

367 can be assumed that the concentration of ITCs contributes to their suppressive effects.

368 Our ITC analysis revealed differences in the pattern of ITC release between B. juncea

369 and S. alba hydrated dry tissues. The calculated ITC/GSL ratios indicate that the GSL 2-

370 propenyl is more efficient than $p$-hydroxybenzyl and benzyl GSLs at producing ITCs.

371 The chemical structure and size of GSLs mainly regulate their efficiency of conversion

372 into ITCs. ${ }^{25,48}$ Our chemical analysis also shows the hydrated dry shoot tissue of S. alba

373 released volatile compounds more rapidly, with the highest concentration recorded within

374 a much shorter time than for B. juncea. The dominant ITC released by B. juncea tissue,

375 allyl ITC, has a lower molecular weight and lower boiling point than benzyl ITC, the

376 dominant compound released by S. alba. However, despite the expected higher volatility

377 of allyl ITC, its concentration in the headspace of hydrolysed powder of the respective

378 plants was comparable to that of benzyl ITC. Although it is likely that the volatility of

379 these ITCs does influence their toxicity, our results suggest that other factors inherent to

380 the dry powders themselves are also important.

381 The hydrolysis process for the dominant aliphatic GSL in B. juncea shoot tissue

382 seemed to follow a longer time course than the dominant aromatic GSL in S. alba.

383 Further, we observed that the release pattern of phenylethyl ITC differed between plant

384 species, following the same pattern as the dominant ITC for each species. The ITC/GSL

385 ratio (indicating the efficiency of production) of the species common aromatic 
386 phenylethyl ITC from the parent GSL 2-phenylethyl was lower in B. juncea tissue than in

387 S. alba. This suggests that other traits inherent to the dry powders, such as plant cell

388 structure or water absorbing capacity, influence GSL hydrolysis and ITC release. These

389 factors probably interact with the characteristics of the chemicals themselves, such as

390 volatility, to determine the eventual ITRC release. ${ }^{48}$ These factors, however, require

391 further investigation.

392 Toxic effects from incorporated B. juncea plant tissue in A. euteiches contaminated

393 soil have been shown to reduce the development of pea root rot, but an effect of ITCs has

394 not always been established. ${ }^{12,46}$ In a closed system, volatile ITCs can easily interact

395 directly with the exposed pathogen. We show that the degree of detrimental effects from

396 ITCs was enhanced as the time of pathogen exposure increased. For A. euteiches growing

397 on CMA agar medium, the lethal dose of ITCs from B. juncea was reached after two

398 hours of exposure, showing the importance of keeping the concentration of effective ITCs

399 high for this period. For an optimal effect in a bio-fumigation process, this suggests the

400 use of a cover after incorporating plant biomass to minimise evaporation of volatiles.

401 This measure was also suggested in earlier studies. ${ }^{47}$

402 The current study shows that brassica plant tissue, its dominant ITCs, their 403 concentration and release pattern, and exposure time are important factors for the 404 suppression of A. euteiches. The results highlight the importance of choosing plant 405 species with the most effective production ratio but also high biomass production to reach 406 optimal concentration levels when GSL containing plants are used for bio-fumigation. 407 The results support the use of a cover to minimise dispersal of ITCs, which should allow 
408 the ITCs to interact directly with the pathogen for a longer period. However, the findings

409 from this study need further verification under field conditions.

\section{ACKNOWLEDGMENTS}

412 The project was funded by the research programme SLU EkoForsk at the Swedish

413 University of Agricultural Sciences. We thank Erika Qvarfordt for technical assistance.

\section{REFERENCES}

416 (1) Papavizas, G. C.; Ayres, W. A. Aphanomyces euteiches. Aphanomyces species and 417 their root diseases in pea and sugarbeet: A Review. Technical Bulletin 1485. US

418 Department of Agriculture, Washington, DC, 1974, 8-9.

419 (2) Persson, L.; Bodker, L.; Larson-Wikstrom, M. Prevalence and pathogenicity of 420 foot and root rot pathogens of pea in southern Scandinavia. Plant Dis. 1997, 81, 171$421 \quad 174$.

422 (3) Gaulin, E.; Jacquet, C.; Bottin, A.; Dumas, B. Root rot disease of legumes caused 423 by Aphanomyces euteiches. Mol. Plant Pathol. 2007, 8, 539-548.

424 (4) Shang, H.; Grau, C. R.; Peters, R. D. Oospore germination of Aphanomyces 425 euteiches in root exudates and on the rhizoplanes of crop plants. Plant Dis. 2000, 84, $426 \quad 994-998$.

427 (5) Hardham, A. R.; Hyde, G. J. Asexual sporulation in the oomycetes. Adv. Bot. Res. $428 \quad \mathbf{1 9 9 7}, 24,353-398$.

429 (6) McGee, J. R.; Coyne, C.; Pilet-Nayel, M-L.; Moussart, A.; Tivoli, B.; Baranger, 430 A.; Hamon, C.; Vandemark, G.; McPhee, K. Registration of pea germplasm lines 
431 partially resistant to Aphanomyces root rot for breeding fresh or freezer pea and dry pea

432 types. J. Plant Reg. 2012, 6, 203-207.

433 (7) European Parliament, Council of the European Union. Regulation (EC) No

$4341107 / 2009$ of the European parliament and of the council of 21 October 2009,

435 concerning the placing of plant protection products on the market and repealing Council

436 Directives 79/117/EEC and 91/414/EEC.

437 (8) Hossain, S.; Bergkvist, G.; Berglund, K.; Mårtensson, A.; Persson, P.

438 Aphanomyces pea root rot disease and control with special reference to impact of

439 Brassicaceae cover crops. Acta Agr. Scand. B-S. P. 2012, 62, 477-487.

440 (9) Lewis, J. A.; Papavizas, G. C. Evolution of volatile sulfur-containing compounds

441 from decomposition of crucifers in soil. Soil Biol. Biochem. 1970, 2, 239-246.

442 (10) Brown, P. D.; Morra, M. J. Control of soil-borne plant pests using glucosinolate-

443 containing plants. Adv. Agron. 1997, 61, 167-231.

444 (11) Kirkegaard, J. A.; Matthiessen, J. N. Developing and refining the biofumigation 445 concept. Agroindustria 2005, 3, 5-11.

446 (12) Muehlchen, A. M.; Rand, R. E.; Parke, J. L. Evaluation of green manures for

447 controlling Aphanomyces root rot of peas. Plant Dis. 1990, 74, 651-654.

448 (13) Lewis, J. A.; Papavizas, G. C. Effect of sulfur-containing volatile compounds and 449 vapors from cabbage decomposition on Aphanomyces euteiches. Phytopathology 1971, $450 \quad 61,208-214$.

451 (14) Angus, J. F.; Gardner, P. A.; Kirkegaard, J. A.; Desmarchelier, J. M.

452 Biofumigation: Isothiocyanates released from Brassica roots inhibit growth of the take453 all fungus. Plant Soil 1994, 162, 107-112. 
455 distribution of glucosinolates and isothiocyanates among plants. Phytochemistry 2001, $456 \quad 56,5-51$.

457 (16) van Dam, N. M.; Tytgat, T. O. G.; Kirkegaard, J. A. Root and shoot 458 glucosinolates: a comparison of their diversity, function and interactions in natural and 459 managed ecosystems. Phytochem. Rev. 2009, 8, 171-186.

460 (17) Kiddle, G.; Bennett, R. N.; Botting, N. P.; Davidson, N. E.; Robertson, A. A. B.; 461 Wallsgrove, R. M. High-performance liquid chromatographic separation of natural and 462 synthetic desulphoglucosinolates and their chemical validation by UV, NMR and 463 chemical ionisation-MS methods. Phytochem. Analysis 2001, 12, 226-242.

464 (18) Smolinska, U.; Morra, M. J.; Knudsen, G. R.; Brown, P. D. Toxicity of 465 glucosinolate degradation products from Brassica napus seed meal towards 466 Aphanomyces euteiches f. sp. pisi. Phytopathology 1997, 87, 77-82.

467 (19) Malik, S. M.; Riley, B. M.; Norsworthy, K. J.; Bridges, W. (jr). Glucosinolate 468 profile variation of growth stages of wild radish (Raphanus raphanistrum). J. Agr. Food 469 Chem. 2010, 58, 3309-3315

470 (20) Wittstock, U.; Halkier, B. A. Glucosinolate research in the Arabidopsis era.

$471 \quad$ Trends Plant Sci. 2002, 7, 263-270.

472 (21) Brown, P. D.; Morra, M. J. Glucosinolate-containing plant tissues as 473 bioherbicides. J. Agr. Food Chem. 1995, 43, 3070-3074.

474 (22) Sang, J. P.; Minchinton, P.; Johnstone, P.; Truscott, R. J. W. Glucosinolate 475 profiles in the seed, root and leaf tissue of cabbage, mustard, rapeseed, radish and 476 swede. Can. J. Plant Sci. 1984, 64, 77-93. 
478 isothiocyanate. Phytochemistry 1985, 24, 715-718.

479 (24) Kirkegaard, J. A.; Sarwar, M.; Matthiessen, J. N. Assessing the biofumigation 480 potential of crucifers. Int. Soc. Hort. Sci. 1998, 459, 105-111.

481 (25) Smith, B. J.; Kirkegaard, J. A. In vitro inhibition of soil microorganisms by 2482 phenylethyl isothiocyanate. Plant Pathol. 2002, 51, 585-593.

483 (26) Smolinska, U.; Morra, M. J.; Knudsen, G. R.; James, R. L. Isothiocyanates 484 produced by Brassica species as inhibitors of Fusarium oxysporum. Plant Dis. 2003, $48587,407-412$.

486 (27) Falk, K. L.; Vogel, C.; Textor, S.; Bartram, S.; Hick, A. Glucosinolate 487 biosynthesis: demonstration and characterization of the condensing enzyme of the chain 488 elongation cycle in Eruca sativa. Phytochemistry 2004, 65, 1073-84.

489 (28) Yuesheng, Z. The molecular basis that unifies the metabolism, cellular uptake and 490 chemopreventive activities of dietary isothiocyanates. Carcinogenesis 2012, 33, 2-9.

491 (29) Abreu, A. C.; Borges, A.; Simoes, L. C.; Saavedra, M. J.; Simoes, M.

492 Antibacterial activity of phenyl isothiocyanate on Escherichia coli and Staphylococcus 493 aureus. Med. Chem. 2013, 9, 756-761.

494 (30) Matthiessen, J. N.; Shackleton, M. A. Biofumigation: environmental impacts on 495 the biological activity of diverse pure and plant-derived isothiocyanates. Pest Manag. 496 Sci. 2005, 61, 1043-1051.

497 (31) Gimsing, A. L.; Kirkegaard, J. A. Glucosinolate and isothiocyanate concentration 498 in soil following incorporation of Brassica biofumigants. Soil Biol. Biochem. 2006, 38, $499 \quad 2255-2264$. 
500 (32) Rongai, D.; Cerato, C.; Lazzeri, L. A natural fungicide for the control of Erysiphe

501 betae and Erysiphe cichoracearum. Eur. J. Plant Pathol. 2009, 124, 613-619.

502 (33) Bång, U. Rhizoctonia solani soil infestation in Sweden and biofumigation studies

503 in vitro. 17th triennial conference of the European association of potato reserchers,

504 Brasov, Romania, Abstract of papers and posters, 2008, 144-146.

505 (34) Schneider, C. L. Use of oospore inoculum of Aphanomyces cochloides to initiate

506 blackroot disease in sugar beet seedlings. J. Am. Soc. Sugar Beet 1978, 20, 55-62.

507 (35) Persson, L.; Larsson-Wikström, M.; Gerhardson, B. Assessment of soil

508 suppressiveness to Aphanomyces root rot of pea. Plant Dis. 1999, 83, 1108-1112.

509 (36) Parke, J. L.; Rand, R. E.; Joy, A. E.; King, E. B. Biological control of Pythium

510 damping-off and Aphanomyces root rot of peas by application of Pseudomonas cepacia

511 or P. fluorescens to seed. Plant Dis. 1991, 75, 987-992.

512 (37) Kabouw, P.; Biere, A.; van der Putten, W. H.; van Dam, N. M. Intra-specific

513 differences in root and shoot glucosinolate profiles among white cabbage (Brassica

514 oleracea var. capitata) cultivars. J. Agr. Food Chem. 2010, 58, 411-417.

515 (38) Buchner, R. Approach to determination of HPLC response factors for

516 glucosinolates. In: Wathelet, J-P. (Ed.), Glucosinolates in Rapeseeds: Analytical

517 Aspects. Martinus Nijho Publishers, Boston, 1987, 50-58.

518 (39) Brown, P. D.; Tokuhisa, J. G.; Reichelt, M.; Gershenzon, J. Variation of

519 glucosinolate accumulation among different organs and developmental stages of

520 Arabidopsis thaliana. Phytochemistry 2003, 62, 471-481. 
521 (40) Valette, L.; Fernandez, X.; Poulain, S.; Lizzani-Cuvelier, L.; Loiseau, A. M.

522 Chemical composition of the volatile extracts from Brassica oleracea L. var. botrytis

523 'Romanesco' cauliflower seeds. Flavour Frag. J. 2006, 21, 107-110.

524 (41) Kjaer. A.; Ohashi. M.; Wilson. J. M.; Djerassi. C. Mass Spectra of

525 Isothiocyanates. Acta Chem. Scand. 1963, 17, 2143-2154.

526 (42) Bodnaryk, R. P. Developmental profile of p-Hydroxybenzyl (p-hydroxybenzyl

527 glucosinolate) in mustard seedlings, Sinapis alba L., and its relationship to insect

528 resistance. J. Chem. Ecol. 1991, 17, 1543-1556.

529 (43) Morra, M. J.; Kirkegaard, J. A. Isothiocyanate release from soil incorporated

530 Brassica tissues. Soil Biol. Biochem. 2002, 34, 163-1690.

531 (44) Kirkegaard, J. A.; Sarwar, M. Biofumigation potential of brassicas. I. Variation in 532 glucosinolate profiles of diverse field-grown brassicas. Plant Soil 1998, 201, 71-89.

533 (45) Rosa, E. A. S.; Heaney, R. K.; Fenwick, G. R.; Portas, C. A. M. Glucosinolates in 534 crop plants. Horict. Rev. 1997, 19, 99-215.

535 (46) Papavizas, G. C. Suppression of Aphanomyces root rot of peas by cruciferous soil 536 amendments. Phytopathology 1966, 56, 1071-1075.

537 (47) Njoroge, S. M. C.; Riley, M. B.; Keinath, A. P. Effect of incorporation of

538 Brassica spp. residues on population densities of soilborne microorganisms and on

539 damping-off and Fusarium wilt of watermelon. Plant Dis. 2008, 92, 287-294.

540 (48) Sarwar, M.; Kirkegaard, J. A.; Wong, P. T. W.; Desmarchelier, J. M.

541 Biofumigation potential of brassicas: In vitro toxicity of isothiocyanates to soil-borne 542 fungal pathogens. Plant Soil 1998, 201, 103-112. 


\section{FIGURE CAPTIONS}

Figure 1. Pea root rot symptoms registered in a bioassay depending on pre-treatment of Aphanomyces oospores with volatile compounds from hydrated dry plant tissues. Pea seedlings were rated for pea root rot three weeks after pea seed sowing. The scale for disease severity index (DSI) is $0-100(\%) .0 \%=$ healthy plant; $25 \%=$ root slightly discolored; $50 \%=$ root extensively discolored but not shrunken; $75 \%=$ root extensively discolored and shrunken; $100 \%=$ root partly or completely rotted or plant dead. ${ }^{36}$ The value of DSI is back transformed from the natural logarithm. Control = water.

Figure 2. Effects of volatile compounds from 60, 100 and $140 \mathrm{mg}$ hydrated Brassica juncea, Sinapis alba and Secale cereale dry shoot tissues on the hyphal growth (cm/day) of Aphanomyces euteiches at $24^{\circ} \mathrm{C}$, in vitro. Control $=$ water.

Figure 3. Effects of volatile compounds from $140 \mathrm{mg}$ hydrated Brassica juncea dry shoot tissues exposed for 40, 80 and 120 min on the hyphal growth (cm/day) of Aphanomyces euteiches at $24^{\circ} \mathrm{C}$, in vitro. Control $=$ water.

Figure 4. Effects of volatile compounds from $140 \mathrm{mg}$ hydrated Brassica juncea and Sinapis alba dry shoot tissues and the chemical standard mixtures, B.juncea-CS and S.alba-CS on the hyphal growth (cm/day) of Aphanomyces euteiches at $22{ }^{\circ} \mathrm{C}$, in-vitro. Control $=$ water 
Figure 5. Release pattern and concentration of allyl, benzyl and phenylethyl ITCs at different time (min) points after adding water to $1 \mathrm{~g}$ dry shoot tissue of A) Brassica juncea (cv. Pacific Gold) and B) Sinapis alba (cv. Architect). 
Table 1. Major isothiocyanates detected from $140 \mathrm{mg}$ hydrated dried plant tissues of Sinapis alba and Brassica juncea and their chemical standard mixtures $1 \mu \mathrm{L}$ each (S.alba-CS and B.juncea-CS). Samples were taken 0-10 min and 60-70 min after adding water, according to the highest peaks with $140 \mathrm{mg}$ dried plant tissues of Sinapis alba and Brassica juncea, respectively.

\begin{tabular}{lllllll}
\hline Treatment & $\begin{array}{l}\text { Allyl } \\
(\mu \mathrm{g} / \mathrm{min})\end{array}$ & $\mathrm{SE}^{\mathrm{e}}$ & $\begin{array}{l}\text { Benzyl } \\
(\mu \mathrm{g} / \mathrm{min})\end{array}$ & $\mathrm{SE}$ & $\begin{array}{l}\text { Phenylethyl } \\
(\mu \mathrm{g} / \mathrm{min})\end{array}$ & $\mathrm{SE}$ \\
\hline S. alba at $0-10 \mathrm{~min}$ & 0.0003 & 0.00002 & 0.0245 & 0.00299 & 0.0026 & 0.00009 \\
S.alba-CS ${ }^{\mathrm{a}}$ at 0-10 min & 0.0013 & 0.00013 & 0.2051 & 0.05291 & 0.0123 & 0.00483 \\
B. juncea at $60-70 \mathrm{~min}$ & 0.3650 & 0.00710 & $\mathrm{nd}^{\mathrm{c}}$ & & 0.0003 & 0.00005 \\
B.juncea-CS ${ }^{\mathrm{b}}$ at 60-70 min & 0.4310 & 0.01100 & $\mathrm{ni}^{\mathrm{d}}$ & & $\mathrm{nd}^{\mathrm{c}}$ & \\
\hline
\end{tabular}

${ }^{a}$ Mixture of chemicals standard for predominant ITCs from S. alba denoted as 'S.albaCS'.

${ }^{\mathrm{b}}$ Mixture of chemicals standard for predominant ITCs from B. juncea denoted as 'B.juncea-CS'.

${ }^{\mathrm{c}}$ Not detected

${ }^{\mathrm{d}}$ Not included in mixture

${ }^{\mathrm{e}} \mathrm{SE}=$ Standard error 
Table 2. Different glucosinolates and concentrations ( $\mu \mathrm{mol} / \mathrm{g})$ in dry shoot tissue of Brassica juncea (cv. Pacific Gold) and Sinapis alba (cv. Architect)

\begin{tabular}{lllll}
\hline Compound & Brassica juncea & SE & Sinapis alba & SE \\
\hline Aliphatic & & & & \\
2-(S)-2-Hydroxybutenyl & $\mathrm{nd}^{\mathrm{a}}$ & $\mathrm{nd}$ & 0.515 & 0.023 \\
5-Methylsulphinylpentyl & $\mathrm{nd}$ & $\mathrm{nd}$ & 0.008 & 0.005 \\
4-Pentenyl & 0.011 & 0.006 & $\mathrm{nd}$ & $\mathrm{nd}$ \\
n-Butyl & 0.032 & 0.011 & $\mathrm{nd}$ & $\mathrm{nd}$ \\
3-Methylthiopropyl & $\mathrm{nd}$ & $\mathrm{nd}$ & 0.013 & 0.004 \\
3-Butenyl & 0.012 & 0.007 & 0.062 & 0.005 \\
2-Hydroxy-3-butenyl & $\mathrm{nd}$ & $\mathrm{nd}$ & 0.018 & 0.001 \\
2-Propenyl & 3.909 & 0.497 & $\mathrm{nd}$ & $\mathrm{nd}$ \\
Unknown & 0.019 & 0.007 & $\mathrm{nd}$ & $\mathrm{nd}$ \\
Aromatic & & & & \\
2-Phenylethyl & 0.119 & 0.016 & 0.068 & 0.005 \\
Benzyl & $\mathrm{nd}$ & $\mathrm{nd}$ & 0.483 & 0.054 \\
p-Hydroxybenzyl & $\mathrm{nd}$ & $\mathrm{nd}$ & 7.935 & 0.981 \\
Indolyl & & & & \\
4-Hydroxy-3-indolylmethyl & 0.006 & 0.004 & $\mathrm{nd}$ & $\mathrm{nd}$ \\
4-Methoxy-3-indolylmethyl & 0.001 & 0.001 & 0.008 & 0.001 \\
3-Indolylmethyl & 0.040 & 0.007 & 0.016 & 0.002 \\
1-Methoxy-3-indolylmethyl & 0.008 & 0.002 & 0.009 & 0.002 \\
Total & 4.156 & & 9.136 & \\
\hline
\end{tabular}

${ }^{a}$ nd, not detected 
Table 3. Volatile compounds $(\mu \mathrm{g} / \mathrm{min})$ in the first two hours after adding water in $1 \mathrm{~g}$ dry shoot tissue of Brassica juncea (cv. Pacific Gold) and Sinapis alba (cv. Architect)

\begin{tabular}{|c|c|c|c|c|}
\hline Compound & Brassica juncea & SE & Sinapis alba & SE \\
\hline \multicolumn{5}{|l|}{ Aliphatic ITC } \\
\hline 3-Butenyl ${ }^{\mathrm{b}}$ & 0.0024 & 0.0003 & 0.0352 & 0.0104 \\
\hline 4-Methylpentyl ${ }^{\mathrm{b}}$ & nd & & 0.005 & 0.0014 \\
\hline Allyl $^{\mathrm{a}}$ & 0.2077 & 0.0211 & 0.0016 & 0.0007 \\
\hline n-Heptyl ${ }^{\mathrm{a}}$ & nd & & 0.0005 & 0.0001 \\
\hline $\mathrm{n}-\mathrm{Hexyl}^{\mathrm{a}}$ & nd & & 0.0024 & 0.0009 \\
\hline n-Pentyl ${ }^{\mathrm{a}}$ & nd & & 0.0008 & 0.0002 \\
\hline Sec-Butyl ${ }^{\mathrm{c}}$ & 0.0022 & 0.0004 & 0.0007 & 0.0003 \\
\hline \multicolumn{5}{|l|}{ Aromatic ITC } \\
\hline Benzyl $^{\mathrm{a}}$ & nd & & 0.1851 & 0.0404 \\
\hline Phenylethyl $^{\mathrm{a}}$ & 0.0112 & 0.0021 & 0.0289 & 0.0046 \\
\hline \multicolumn{5}{|l|}{ Others } \\
\hline (z)-3-Hexen-1-ol ${ }^{\mathrm{a}}$ & nd & & 0.0017 & 0.0002 \\
\hline (z)-3-Hexenal ${ }^{\mathrm{a}}$ & 0.0019 & 0.0006 & 0.0024 & 0.0007 \\
\hline 3.5-Octadien-2-one ${ }^{\mathrm{d}}$ & 0.0014 & 0.0003 & 0.0023 & 0.0005 \\
\hline Allyl thiocyanate ${ }^{b}$ & 0.0211 & 0.0022 & nd & \\
\hline Benzaldehyde $^{\mathrm{a}}$ & 0.0024 & 0.0004 & 0.0058 & 0.0011 \\
\hline Benzyl isocyanate $^{\mathrm{a}}$ & nd & & 0.0014 & 0.0003 \\
\hline 2-phenylpropane ${ }^{\mathrm{d}}$ & 0.0088 & 0.0047 & 0.0054 & 0.0032 \\
\hline Diallyl disulphide $^{\mathrm{a}}$ & nd & & 0.0003 & 0.0001 \\
\hline Dimethyl disulphide $^{\mathrm{a}}$ & nd & & 0.0005 & 0.0003 \\
\hline Total & 0.2591 & & 0.28 & \\
\hline
\end{tabular}

${ }^{a}$ mass spectrum and retention index (Kovats Index KI) match with National Institute of Standards and Technology standard library (NIST 08) and with an authentic standard ${ }^{\mathrm{b}}$ mass spectrum match in NIST08 and KI concurs with published $\mathrm{KI}^{40}$ ${ }^{c}$ no satisfactory match in NIST08 but mass spectrum matches published spectrum ${ }^{41}$ ${ }^{\mathrm{d}}$ match in NIST08 


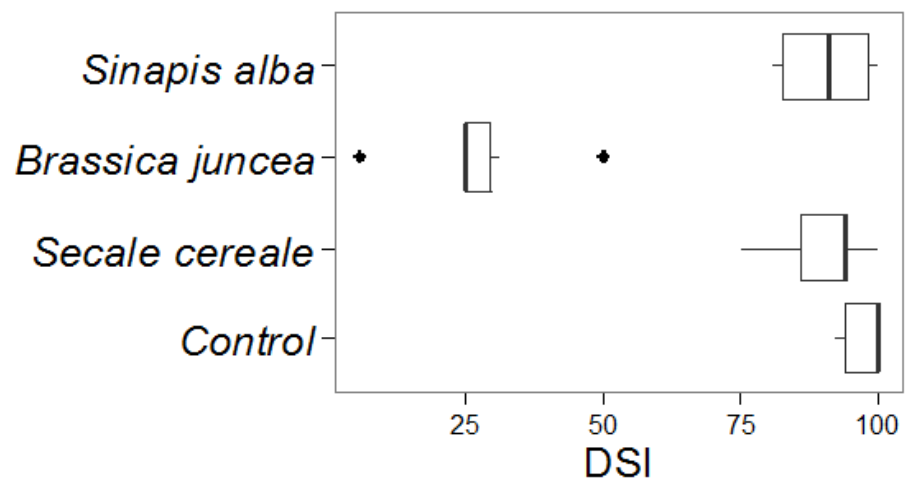

Figure 1 


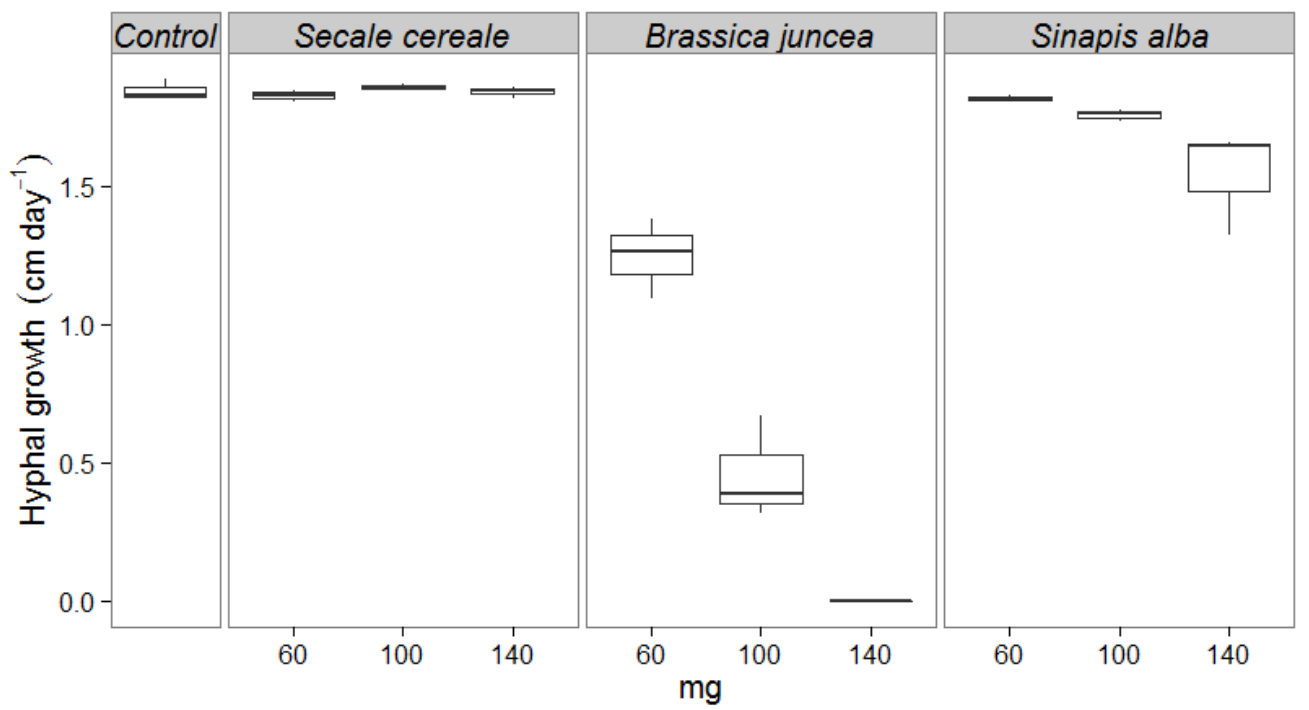

Figure 2 


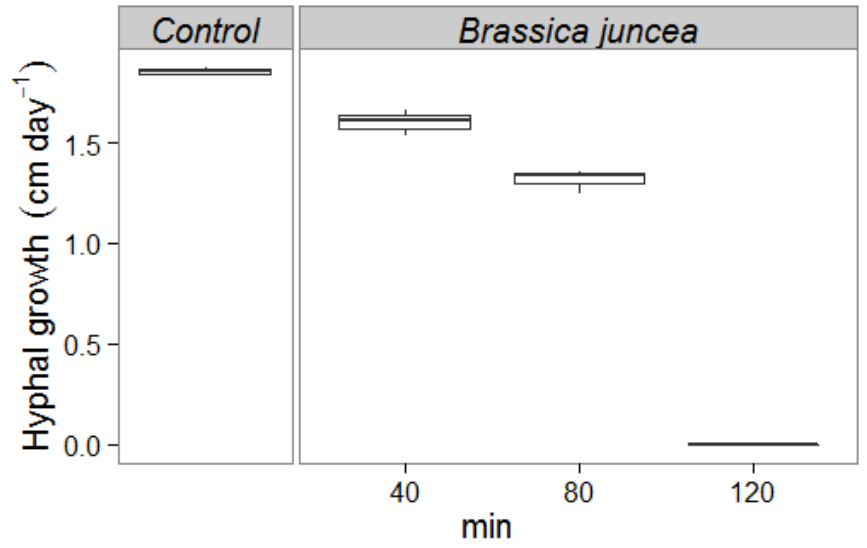

Figure 3 


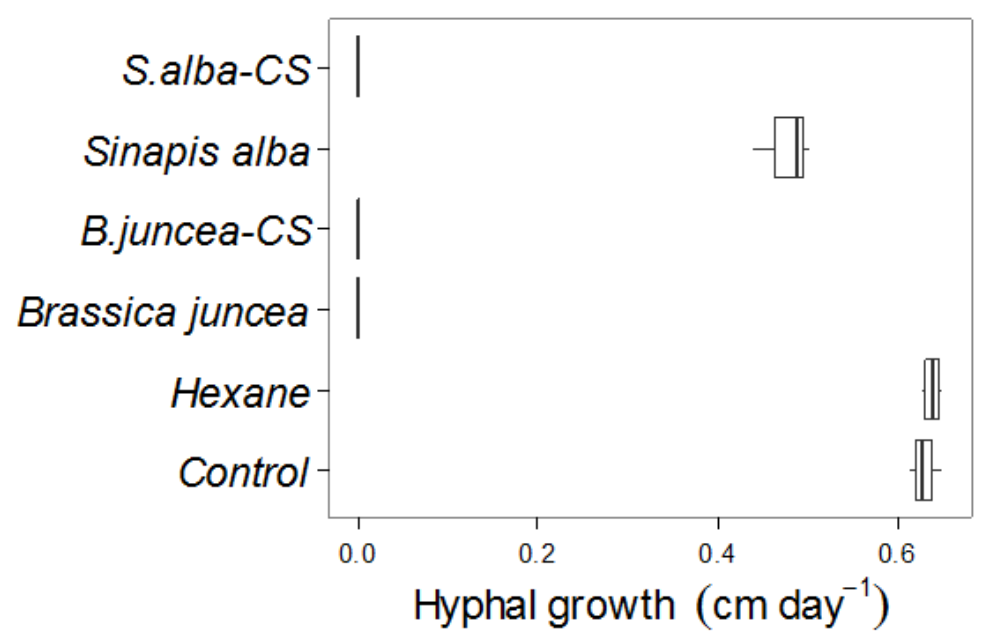

Figure 4 

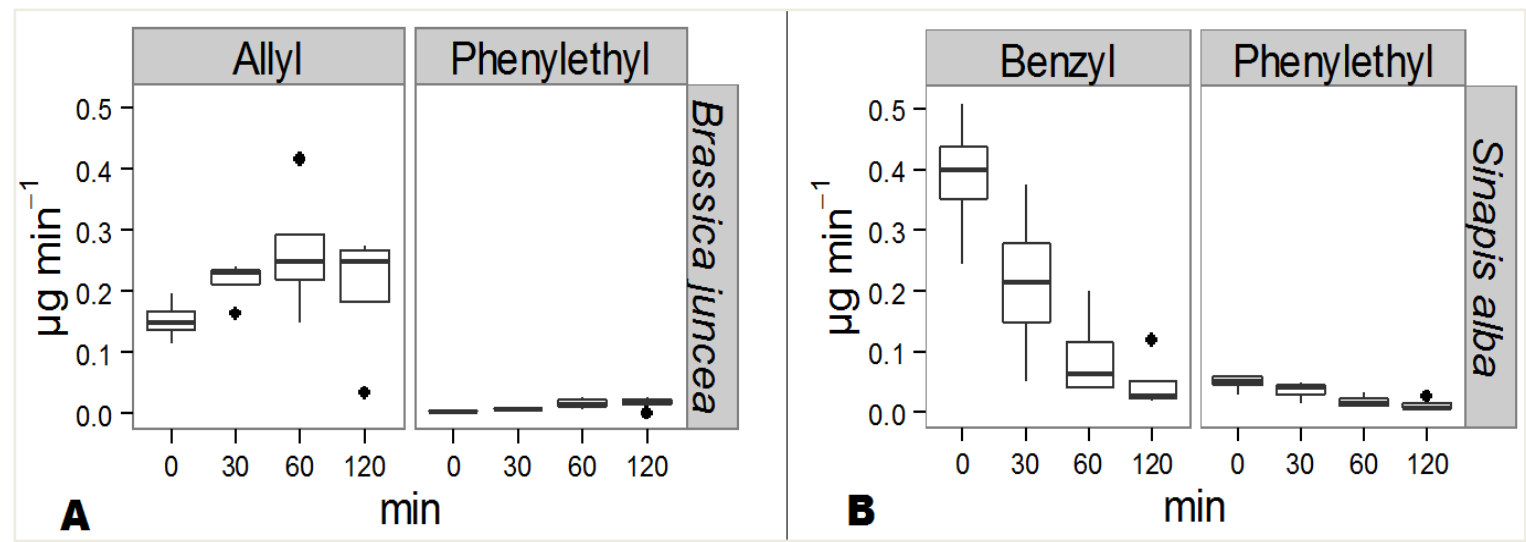

Figure 5 